Crime, Histoire \& Sociétés / Crime, History \& Societies

Vol. 21, n² | 2017

L'histoire de la criminalité et de la justice pénale : propositions de recherche pour le $21^{\mathrm{e}}$ siècle

\title{
Writing a Global History of Crime and Punishment: The Great Challenge
}

Pieter Spierenburg

\section{(2) OpenEdition}

\section{Journals}

Electronic version

URL: http://journals.openedition.org/chs/1782

DOI: $10.4000 /$ chs. 1782

ISSN: 1663-4837

\section{Publisher}

Librairie Droz

\section{Printed version}

Date of publication: 31 December 2017

Number of pages: $31-39$

ISSN: $1422-0857$

\section{Electronic reference}

Pieter Spierenburg, "Writing a Global History of Crime and Punishment: The Great Challenge", Crime, Histoire \& Sociétés / Crime, History \& Societies [Online], Vol. 21, n² | 2017, Online since 19 July 2020, connection on 12 January 2021. URL: http://journals.openedition.org/chs/1782 ; DOI: https://doi.org/ $10.4000 /$ chs. 1782 


\title{
Writing a Global History of Crime and Punishment: The Great Challenge
}

\author{
Pieter Spierenburg
}

$\mathrm{T}$ o write a truly global history of any subject is a formidable task. That is why the word "challenge" figures in my title. For my part, I have made a few tentative steps toward this ambitious goal with respect to the theme of violence. Writing the global history of all crime and punishment surely has to be a collective enterprise, stretching over more than one generation of scholars. Up to now, violence, in its various manifestations, has indeed been the preferred subject when it comes to a world-wide perspective within the field. Next to this theme, there is an emerging global history of prisons and labor camps. These two subjects constitute my main focus. In this brief essay a claim of comprehensiveness is out of the question. I am offering some reflections and suggestions, based on the literature that I happen to have read, in the hope that others find them useful. As much as possible, I will avoid repeating data from my earlier article in this journal, referring to it only when this is necessary to provide a context ${ }^{1}$. Since relatively few publications cover all of the world, global history often means non-Western history. In order to leave room for the other contributions in this section, I am striving to deal with separate world regions only when this is relevant for the global perspective.

Perhaps surprisingly to younger scholars in the field, one of the first global histories of crime appeared as early as the 1970s - the very decade which witnessed the emergence of the historical study of criminal behavior and punishment as a distinct field. The research in question was done by a team under the direction of Ted Robert Gurr and published in two volumes: an extensive and an abridged one $^{2}$. For their global analysis, covering the nineteenth and twentieth centuries, they selected the cities of London, Stockholm, Sydney and Calcutta. The team examined all offenses committed, based almost exclusively on criminal and police statistics. In his introduction Gurr acknowledges that the content of what is considered crime differs across societies. He also briefly discusses the problem of the relation between "true" crime and criminal statistics: while the first is unknowable, the statistical data reflect the extent of public and official concern about crime. He intended to study this concern against the background of the issue of public order, indicated by events such as strikes. Hence both volumes conclude with an outline of a theory of public disorder. Despite Gurr's caveats, the many graphs and tables that form the core of the

Spierenburg (2014).

2 Gurr et al. (1976). This is the abridged ed. in collaboration with Peter N. Grabosky, Richard C. Hula, Louis H. Masotti, David Peirce, Leif Persson and Sven Sperlings. Gurr et al. (1977), the extensive ed. with Peter N. Grabosky and Richard C. Hula as co-authors and David Peirce, Leif Persson and Sven Sperlings as contributors. 
two books testify to a considerable faith in quantification that later historians have tempered. Within the community of historical students of crime today, Gurr is chiefly remembered for his subsequent pioneering effort of constructing long-term homicide rates.

The effort of Gurr's team had no immediate followers; in the 1980s global studies of criminality or punishment remained rare. One exception is a study of concentration camps since 1896 , extending over four continents ${ }^{3}$. The global history of crime and criminal justice did not really take off until the second half of the 1990s. Examples include a collective volume on massacres resulting from a conference at the University of Warwick held in $1995^{4}$. The book includes contributions on the murder of Circassians by Russian troops and the extermination of a religious community in Brazil in the second half of the nineteenth century and, in the twentieth, the genocides in Namibia, Nanking and Indonesia. As a curious detail, the editors reckon animals among massacre victims, exemplified by a contribution on the elimination of wolves in the United States. Another collective volume examines punishment, in particular imprisonment, throughout the African continent in the nineteenth and twentieth centuries $^{5}$. Together these two books introduce my main themes of violence and the prison. I will discuss the global work published in the twenty-first century in a more or less thematic way.

Whereas global history is defined primarily by a lack of geographical boundaries, it equally observes no chronological limits. Thus, it includes studies of violence and criminal justice in Mediterranean and Near-Eastern Antiquity or in pre-unification China. Some scholars go back even further in time, as a consequence of which we can speak of an emerging history of prehistoric violence. A common technique is to inspect ancient graves, collective as well as individual, which contain skeletons showing signs of violent death ${ }^{6}$. The present state of skeleton investigation allows the preliminary conclusion that aggression among human communities was a recurrent feature of prehistoric life. This research can be supplemented by an even more exciting new field, the study of the repartition of types of DNA in living populations. In particular, this involves Y-chromosomes, which only males possess, and mitochondrial (mt) DNA which is transferred from mother to daughter. Because of recurrent mutations these hereditary markers can be arranged according to their dating, whereupon the distribution of types in selected populations allows conclusions about human migration. As yet, we have little knowledge of the extent to which this migration was accompanied by violence, but let me cite two examples. One is still contested, while the other has been confirmed recently.

The first successful venture of humans out of Africa led them eventually to Australia, with just sparse communities staying behind in coastal areas. Thus a community of men with Y-chromosome M130 and women with mtDNA of the haplogroup M lived happily in Southern India, until a band of invaders surprised them. The males among the invaders had a Y-chromosome with the code M20. This variant originated in Iran or Northern India about thirty thousand years ago. I estimate

Kaminski (1982).

Levene and Roberts (1999).

Bernault (1999).

6 Compare Armit (2011). See also several other contributions to the issue in question of the British Journal of Criminology. Also: Meyer et al. (2015). 
that it took the M20 men exactly 1,000 years from acquiring their mutation to reach their victims ${ }^{7}$. Hence the clash of populations occurred some 29,000 years ago. That the M20 committed a massacre follows from the fact that they have bequeathed their Y-chromosome to c. 50 percent of the men in present-day Southern India, whereas less than 5 percent of the men living in the Indian subcontinent nowadays carry M130 and in the South even fewer. By contrast, among present-day women on the Indian subcontinent the mtDNA haplogroup $\mathrm{M}$ accounts for a substantial 20 percent. According to Spencer Wells this means that the invaders took wives from the coastal population and either killed the coastal men or prevented them from reproducing ${ }^{8}$. I add that the M20 prevented their victims from reproducing by killing them. This massacre is contested, however, due to a claimed unrepresentativeness of Wells' sample of modern South-Indian men.

The second example, the extermination of Cro-Magnons in Europe, has been recently confirmed. Cro-Magnons is the collective name for the population that lived in Europe before the last glacial maximum, retreated to its Southern fringes during this maximum and resettled the continent thereafter. During all this time they were hunter-gatherers. The crucial question is whether the subsequent spread of agriculture from the Middle East to Europe was cultural or demic. Cultural stands for no significant population movement: in each generation groups of hunter-gatherers learned from their neighbors how to become farmers. Demic, on the other hand, implies invasion and annexation: pressed by overpopulation in their native home, groups of agriculturalists migrated to hunting grounds further away and converted these to farm land. As many authors assume, demic expansion usually leads to conflict and violence. Native groups most likely put up resistance, unsuccessful in the end, to the forcible taking of their land. A recent study provides firm support for the thesis of a demic expansion of farming into Europe ${ }^{9}$. It is based on the resequencing of MSY DNA in a sample of 334 males from two Near-Eastern and fifteen European populations. The authors claim two major waves of immigration, the first of which, dated from Y-chromosomes at between 7-8 ky BP, involved the arrival of farmers from the Near East. In addition the authors refer to a study of mtDNA, which shows a massive shift in haplogroup composition in Central Europe around $7.5 \mathrm{ky} \mathrm{BP,} \mathrm{from}$ haplogroups characteristic for hunter-gatherers to those characteristic for farmers. In other words, the invading farmers arrived as couples. Since the newcomers most likely were lightly pigmented and the Cro-Magnons most likely darkly pigmented, this clash of populations can be termed the first white-on-black genocide.

The study of DNA in order to track past population movements, whether accompanied by violence or not, is an exciting new field that should draw the attention of crime historians. Whether the latter will respond, I don't know. While some scholars are eager to identify the directions in which research traditions are moving, it is not my habit to predict the future. Wherever there is talk of trends in research in this essay, I will restrict myself to statements of desirability. In this case I find the integration of modern DNA research elucidating the deep human past into the historiography of crime and justice highly desirable.

Estimate based on Flood (2006, p.176).

Wells (2002, p.113).

9 Batini et al. (2015). 
We know of course that the demic expansion of agriculture - and eventually mining and industry - repeated itself in historic times, most notably in North America and Australia. Discussing the San of Southern Africa, Mohamed Adhikari provides an excellent outline of the pattern of events taking place when agriculturalists arrive in an area occupied by hunter-gatherers. It would be worth quoting it entirely, but let me try to capture it in a few points: (1) The farmers' herds consume large amounts of grazing and water, damaging the existing ecosystem. (2) The hunter-gatherers find their seasonal migrations disrupted and their food supplies diminishing. (3) Native groups put up resistance, to which the foreign immigrants react, leading to a spiral of violence. (4) The weakness of the colonial state, unable to control frontiersmen, prevents it from mitigating this violence. (5) Access to world markets stimulates the introduction of laws of private ownership that are contrary to hunter-gatherer conceptions about the relationship between people and the land. (6, which perhaps should be 1) The newcomers view the territory as empty to begin with; they liken the natives to animals who merely roam around the land without cultivating $\mathrm{it}^{10}$.

Situations conforming to this pattern have been subsumed under the heading of settler colonialism, one of Ben Kiernan's types of genocide ${ }^{11}$. Adhikari amply discusses the labels that might be put on the destruction of San societies. He offers yet another personal definition of genocide "[...] the intentional physical destruction of a social group in its entirety, or the intentional annihilation of such a significant part of the group that it is no longer able to reproduce itself biologically or culturally, nor sustain an independent economic existence." 12 As he subsequently specifies, the encompassing term "social group" serves to circumvent the restrictions inherent in the UN Convention's or Raphael Lemkin's definition of the term. Although the inability to reproduce itself must necessarily lead to extinction, Adhikari admits that the target group may be revitalized over time. Today some 100,000 San remain, almost all in Botswana and Namibia though. I do not intend to repeat my discussion about the relative merits of the concepts of genocide, massacre and organized murder here $^{13}$. I observe that genocide studies is a flourishing and largely independent field with its own journals and associated conferences. For the further development of a global history of crime a fuller integration with this independent field would be clearly advantageous.

The encounter of two peoples with a large difference in power usually brings with it a demeaning vocabulary denoting the less powerful party. We can blame the colonizing or conquering nation for this, but for adequate scholarship it is more useful to consider the pejorative labels as a property of established-outsider relationships. As such, their function in the entire figuration in which the two peoples find themselves can be analyzed most fruitfully. One indication for a modest measure of emancipation of outsider groups is the tendency of modern researchers to avoid the denigrating labels of the past. Personally, I avow the principle that every ethnic or racial group

10 Adhikari (2011, p.18-19). Compare Madley (2015, p.99-100). It is an intriguing irony that, while we all have evolved from the common ancestor of chimps and humans, likening specific human groups to animals counts as the epitome of racist thinking.

11 Kiernan (2007, p.165-390).

12 Adhikari (2011, p.12).

13 Compare Spierenburg (2014, p.101-102). Anderson (2014) subsumes the fate of North-American Indians under the heading of ethnic cleansing. 
should be called by the name its members prefer. Historians no longer refer to the San as Bushmen, while the former "Hottentots" are now called Khoikhoi. Yet there are difficulties with these apparently neutral labels. Because the San actually consisted of a variety of ethnicities and even the difference with the Khoikhoi was not always clear, some authors denote them together as Khoisan. On the other hand, for long the two were distinguished according to their way of life, the Khoikhoi being indigenous cattle farmers and the San hunter-gatherers. If an individual went from hunting to farming or vice versa, the ethnic label changed accordingly ${ }^{14}$. As an unwelcome reality, San is a pejorative Khoikhoi word for hunter-gatherer with the connotation of thief or vagabond. Some authors therefore again prefer Bushman. Incidentally, much of the violence against South-Africa's indigenous peoples was committed by so-called trekboeren, who roamed around in oxen-wagons with their cattle not unlike the Khoikhoi's way of life.

The difficulties with ethnic terminology are far from confined to South-Africa. Maroon, for example, now the commonly accepted word for runaway slaves and their descendants in South America and the Carribean, is nevertheless rejected by some members of this group. The reason lies in the word's Spanish origin, cimarron, which originally referred to stray cattle ${ }^{15}$. Yet no one wants to return to terms such as Bush Negro, once an accepted label for Maroons in Suriname (used by urban blacks as well). Thus, the problem of "politically correct" terminology is far from solved. An argument can be made for flatly taking the original pejorative labels as neutral historical terms. Thus, historians of homosexuality for long have adopted sodomy, a word recurrent in their sources, as a descriptive term. Perhaps this was easy in their case, as after all the label merely refers to a city on the shore of the Dead Sea. Incidentally, the history of slavery constitutes one more field whose integration into crime and justice history is a desirability ${ }^{16}$. As to still other themes connected to global violence, I have to leave them undiscussed ${ }^{17}$.

Quite another word that continues to be problematic and to give rise to misunderstandings is that of civilization. Europeans freely used this word all over the world, notably in colonial situations. For them, to civilize native men and women could mean such diverse things as converting them to Christianity or making them respect private property. This observation refers to the emic conception of civilization, which always has to be distinguished from its use as a scholarly concept by Norbert Elias and others. Even in its "neutral" sense civilization, as Elias repeatedly emphasized, functions as a tool of power. Considering themselves as civilized enhanced the internal cohesiveness of European elites, while all other groups partly adopted the negative label pinned on them. Yet, these elites had no valid reason to consider their standards of conduct as their own merit; these resulted merely from being born around 1900 instead of around 1300. In colonial societies Europeans observed some habits, like frequent spitting, that went against their acquired standards. In addition,

14 Penn (2005, p.4-9).

15 Hoden van Velzen and Hoogbergen (2011, p.2 note 1). See also Thompson (2006).

16 For one combination of murder and slavery, see Krikler (2012). See also Worden and Groenewald (2005).

17 For an attempt to make a beginning with the global history of lynching, see Thurston (2011). For a world wide study of gangs, going back in some cases to the 1970s, see Hazen and Rodgers (2014). One more intriguing case concerns the so-called women's war in Nigeria 1929, see Falola and Paddock (2011) and Matera et al. (2012). 
however, their discourse of civilization led to misrepresentations and exaggerated views of native cultures.

For one thing, these views led to what may be called the paradox of colonial punishment. Within Europe in the course of the nineteenth century, politicians, lawyers and the educated public had come to think that criminal justice aimed at the mind rather than the body. They believed that they treated lawbreakers in a civilized manner. In colonial societies, on the other hand, despite the rhetoric of bringing civilization, quite different attitudes prevailed. Mild penalties, colonial officials argued, failed to impress the native population precisely because of its uncivilized nature. Consequently, the argument continued, the maintenance of order often necessitated more severe forms of criminal justice. Among other measures, this caused colonial executions to remain public well into the interwar period, as was the case in $\mathrm{Congo}^{18}$. European elites considered such shows necessary, even though they, except for the French, had come to see these as unfit for the eyes of their lower classes at home.

This observation introduces the global history of punishment and social control, with which I will conclude. Within it, at least two research themes can be identified. One is relatively specific, inquiring into the origins of the concentration camp. The word itself is tainted to this day by its association with the Nazi régime. Recent historiography, on the other hand, stresses the colonial origins of the concentration camp $^{19}$. Its history is usually taken to begin in 1896 during the Cuban war of independence, with the Spanish policy of reconcentración that cost the lives of over 150,000 inhabitants. Similarity of a name, however, does not necessarily mean similiarity of purpose and character. The British found concentration camp the best term for the shelters receiving displaced persons during and immediately after the Boer War. These camps had no fences around them and the inmates could go out during the day. Yet the strict regulations prevailing there ensured that the inmates, Afrikaners as well as blacks, experienced life in these places as akin to imprisonment. Driven from their farms by the British, they had no choice but to enter them ${ }^{20}$. Combatants captured during the war and afterwards as guerillas, however, totaling over 20,000, were incarcerated in prison camps in St. Helena, Bermuda, India and Ceylon ${ }^{21}$. Joseph Goebbels tried to capitalize on the events in South-Africa by sponsoring the movie Ohm Krüger, which conveyed the message that the British had invented the concentration camp and practiced it more ruthlessly than other nations. After World War II, with Paul Kruger's filmish prophesy of the destruction of Britain unfullfilled, a few Spanish historians emphasized the Prussian roots of general Valeriano Weyler, the architect of reconcentración, in an attempt to demonstrate that the concentration camp was a German rather than a Spanish invention ${ }^{22}$.

To concentrate on a particular word, then, brings us little in the way of analysis. It will not do, moreover, to make a crude distinction between extermination and labor camps. From the late nineteenth century on, confinement in one way or another

\footnotetext{
18 Reybrouck (2010, p.174-175).

19 Especially Zimmerer (2011).

20 van Heyningen (2013, p.2-4 and 97).

21 Higginson (2015, p.78-84).

22 Kaminski (1982, p.34-37); https://en.wikipedia.org/wiki/Ohm_Krüger (March 1, 2017).
} 
was a feature of nearly all non-Western countries, both colonial and independent. In the prisons and camps concerned, labor always played a central role. This makes the Western history of penality, with its nineteenth-century enthusiasm for solitary confinement, unique to Europe and to a lesser extent the United States. Everywhere else labor prevailed. Colonial prisoners often related to compulsive work in a double sense. First, the colonizers instituted a system of exploiting the natives' labor power; second, evaders faced imprisonment at hard labor. For an overview of the research into confinement and forced work in non-Western societies, it suffices to refer to the excellent synthesis and bibliography by Mary Gibson ${ }^{23}$. One study published since then deals with the Ottoman Empire in the late nineteenth and early twentieth centuries. From it I take this comprehensive passage: "By the middle of the nineteenth century, incarceration with hard labour, however, no longer involved serving in the galleys at the Imperial Shipyards, although it maintained the name kürek. Tanzimatera reformers also established several labour camps for prisoners in places such as Cyprus, Rhodes and Mytilene. By the early twentieth century, the Ottoman Prison Administration built prison factories in major urban areas. Finally, during WW I the Ottoman regime pressed many prisoners into work batallions to build roads and raise crops as part of the empire's war effort"24.

The global history of imprisonment and social control will receive an impetus from an ongoing project hosted by two Amsterdam institutes and entitled Four Centuries of Labor Camps. Its subprojects deal with prisons in Hamburg since the early seventeenth century, convict labor in Indonesia since the late eighteenth century, penal colonies in Italy and its African dominions from 1860 to 1945 and a comparison between the Tsarist Katorga and the Communist Gulag in Western Siberia ${ }^{25}$. The global history of crime, finally, could be greatly enhanced by renewed attention for non-violent offenses, as practiced by the Gurr team but now perhaps in a less rigidly quantitative manner. An interesting study of Maya women, mainly market vendors, in Guatemala between 1898 and 1944 constitutes one buildingblock. While being prosecuted for such offenses as selling aguardiente clandestino and cross-dressing, these women managed to survive in a highly patriarchal society ${ }^{26}$. More of such building-blocks are surely desirable.

Pieter Spierenburg

Professor Emeritus

Erasmus University, Institute for War and Genocide Studies

Binnenkant 27

1011 BJ Amsterdam, NL

spierenburg@law.eur.nl

\footnotetext{
23 Gibson (2011).

24 Schull $(2014$, p.24).

25 The researchers involved are Ralf Futselaar, Klaas Stutje, Francesca di Pasquale and Zhanna Popova.

26 Carey (2013).
} 


\section{BIBLIOGRAPHY}

Adhikari, M. (2011) The anatomy of a South African genocide. The extermination of the Cape San peoples, Athens: Ohio University Press.

Anderson, G.C. (2014), Ethnic cleansing and the Indian. The crime that should haunt America. Norman, Oklahoma: University of Oklahoma Press.

Armit, I. (2011) Violence and society in the deep human past, British Journal of Criminology, 51,3, p.499-517.

Batini, C. et al. (2015) Large-scale recent expansion of European patrilineages shown by population resequencing, Nature Communications, 6, doi:10.1038/ncomms8152.

Bernault, F. (Dir.) (1999) Enfermement, prison et châtiments en Afrique du $19^{e}$ siècle à nos jours, Paris: Karthala.

Carey, D. Jr. (2013) I ask for justice. Maya women, dictators and crime in Guatemala, 18981944, Austin: University of Texas Press.

Falola, T. and Paddock, A. (2011) The women's war of 1929. A history of anti-colonial resistance in Eastern Nigeria, Durham: Carolina Academic Press.

Flood, J. (2006) The original Australians. Story of the Aboriginal people, Crows Nest, NSW: Allen \& Unwin.

Gibson, M. (2011) Global perspectives on the birth of the prison, American Historical Review, 116, 4, p.1040-1063.

Gurr, T. R. et al. (1976) Rogues, rebels and reformers. A political history of urban crime and conflict, Beverley Hills: Sage.

Gurr, T. R. et al. (1977) The politics of crime and conflict. A comparative history of four cities, Beverley Hills: Sage.

Hazen, J. M. and D. Rodgers (Eds.) (2014) Global gangs. Street violence across the world, Minneapolis: University of Minnesota Press.

Heyningen van, E. (2013) The concentration camps of the Anglo-Boer war. A social history, Johannesburg: Jacana Media.

Higginson, J. (2015) Collective violence and the agrarian origins of South African Apartheid, 1900-1948, Cambridge: Cambridge Unniversity Press.

Kaminski, A. (1982) Konzentrationslager 1896 bis heute. Eine Analyse, Stuttgart: Kohlhammer.

Kiernan, B. (2007) Blood and soil. A world history of genocide and extermination from Sparta to Darfur, New Haven, London: Yale University Press.

Krikler, J. (2012), A chain of murder in the slave trade. A wider context of the Zong massacre, International Review of Social History, 57, 3, p.393-415.

Levene, M. and P. Roberts (Eds.) (1999) The massacre in history, New York: Berghahn.

Madley, B. (2015) Reexamining the American genocide debate. Meaning, historiography and new methods, American Historical Review, 120, 1, p.98-139.

Matera, M. et al. (2012) The women's war of 1929. Gender and violence in Colonial Nigeria, Houndmills: Palgrave Macmillan.

Meyer, C. et al. (2015) The massacre mass grave of Schöneck-Kilianstädten reveals new insights into collective violence in Early Neolithic Central Europe, Proceedings of the National Academy of Sciences (PNAS), 112, 36, p.11217-11222. 
Penn, N. (2005) The forgotten frontier. Colonists and Khoisan on the Cape's Northern frontier in the 18th century, Athens: Ohio University Press.

Reybrouck, D.V. (2010) Congo. Een geschiedenis, Amsterdam: De Bezige Bij.

Schull, K. F. (2014) Prisons in the Late Ottoman Empire: Microcosms of modernity, Edinburgh: Edinburgh University Press.

Spierenburg, P. (2014) Toward a global history of homicide and organized murder, Crime, Histoire \& Sociétés/ Crime, History \& Societies, 18, 2, p.99-116.

Thoden van Velzen, H.U.E. and W. Hoogbergen (2011) Een zwarte vrijstaat in Suriname. De Okaanse samenleving in de achttiende eeuw, Leiden: KITLV Uitgeverij.

Thompson, A.O. (2006) Flight to freedom. African runaways and maroons in the Americas, Kingston, Jamaica: University of the West Indies Press.

Thurston, R.W. (2011) Lynching:American mob murder in global perspective, Farnham Ashgate.

Wells, S. (2002) The journey of man. A genetic odyssey, Princeton: Princeton University Press.

Worden, N. and G. Groenewald (Eds.) (2005) Trials of slavery. Selected documents concerning slaves from the criminal records of the Council of Justice at the Cape of Good Hope, 17051794, Cape Town: Van Riebeeck Society for the Publication of South African Historical Documents.

Zimmerer, J. (2011) Von Windhuk nach Auschwitz? Beiträge zum Verhältnis von Kolonialismus und Holocaust, Berlin: LIT Verlag. 